\title{
Project-Based Learning on the Topic of Aromatic Wax Production
}

\author{
Nguyen Ngoc Giang \\ Banking University, Ho Chi Minh City, Vietnam. \\ Email: nguvenngocgiang.net@gmail.com Tel: (+84)908576218
}

\section{Abstract}

Project-based learning is one of the most effective and successful teaching methods for STEM topics. Project-based teaching is an open-ended teaching method that helps teachers stimulate students' initiative and teamwork skills and promote creativity. Of the interdisciplinary STEM topics, teaching students how to produce aromatic wax proved an interesting topic, causing excitement to students. Through collaborative teaching, this research has shown that students are very interested in learning to produce aromatic wax. The research results also show that there are five factors that greatly affect project-based teaching: (1) Teachers must split the class into groups to implement projects effectively; (2) Topics must be attractive and motivate students to appreciate, explore and produce STEM products; (3) Students must have a positive attitude, unafraid of encountering difficulties and challenges in completing STEM tasks; (4) Students must be competent to implement STEM products; (5) Students must be facilitated by their school and their parents to complete the STEM tasks. The research findings have important implications for proposing a specific project-based learning curriculum on the STEM topic of aromatic wax production.

Keywords: Project-based learning, Producing aromatic wax, Point of view, Project-based learning model, Perspectives, STEM.

Citation | Nguyen Ngoc Giang (2021). Project-Based Learning on the Topic of Aromatic Wax Production. Journal of Education and eLearning Research, 8(4): 395-407.

History:

Received: 18 May 2021

Revised: 5 October 2021

Accepted: 10 November 2021

Published: 20 December 2021

Licensed: This work is licensed under a Creative Commons

Attribution 3.0 License (oc) Er

Publisher: Asian Online Journal Publishing Group
Funding: This study received no specific financial support.

Competing Interests: The author declares that there are no conflicts of interests regarding the publication of this paper.

Transparency: The author confirms that the manuscript is an honest, Transparency: The author confirms that the manuscript is an honest,
accurate, and transparent account of the study was reported; that no vital accurate, and transparent account of the study was reported; that no vital
features of the study have been omitted; and that any discrepancies from the features of the study have been omitted;
study as planned have been explained.

Ethical: This study follows all ethical practices during writing.

\section{Contents}

1. Introduction

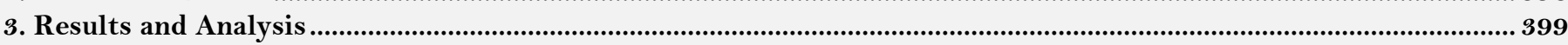

4. Conclusion 406

References. 


\section{Contribution of this paper to the literature}

This study contributes to the existing literature by designing and delivering a Project-Based

Learning topic on aromatic wax production in Vietnam.

\section{Introduction}

Project-based teaching is a student-centered teaching method, which has so far proved very effective in adapting to today's rapidly changing world. Project-based teaching methods improve students' initiative and critical thinking and encourage them to conduct group discussions. Project-based teaching is an effective alternative to traditional education because it represents a shift from education that focuses on what learners gain, i.e., learning outcomes, to a focus on the learning process itself (Uziak, 2016). Project-based teaching has some advantages and disadvantages (see Table 1). In project-based teaching, teachers act as advisors, guides and helpers. Students participate in choosing a study topic that is suitable for their level of knowledge and individual capacity. Students are allowed to work collaboratively and choose the right task. Learning projects require collaboration and the assignment of tasks among team members. Thus they help develop students' willingness and skills to work collaboratively with other participants, as well as teamwork between teachers and students participating in the project. Learning projects are associated with practical contexts and social life. They have a positive impact on social life. Through learning projects, students develop the ability to integrate theory and practice, as well as test, reinforce, and expand their theoretical and practical understanding to solve complex problems. The project's products can be immediately applied to life. These products can be claimed and used (Nguyen, 2020).

Our paper aims to answer the following questions:

1. What is the Project Concept?

2. What are some perspectives on Project-Based Teaching?

3. What are the characteristics of Project-Based Teaching?

4. What is the Project-Based Teaching process?

5. How can we offer a concrete illustrated example of Project-Based Teaching on the topic of aromatic wax production?

This study analyzes the project concept behind Project-Based teaching and seeks to uncover the features of Project-Based teaching. In addition, this study contributes a new Project-Based teaching process. Specifically, the paper supplies a concrete illustrated example of Project-Based teaching on the topic of aromatic wax production.

This paper has four sections. The introduction outlines the research questions and the paper's contributions. The next section will describe the research method. The third section presents the results and analysis. The fourth and final section presents the conclusions.

\section{Research Method}

\subsection{Project Concept}

A project is understood as a scheme, draft or plan that needs to be implemented to achieve the set goals. The project concept is used in production, business, scientific research and social management and, in the field of education and training, refers to a specific method or form of teaching (Pham, 2013).

The term "project" is commonly used in engineering as a "unit of work." Projects are often defined in relation to the customer element. In engineering, almost every task performed is related to a project. Projects will be of different sizes and involve different timings. Projects will have various levels of complexity, but all will in some way involve a certain expertise in a field. Small projects may involve only a single area of technical expertise, but larger projects will be multidisciplinary and may possibly integrate different industries. In order to accomplish a project in practice, the integration of knowledge, skills, attitudes, team cooperation and other related factors is extremely important (Mills \& Treagust, 2003). Projects are complex tasks that are based on challenging questions or issues, involving people solving problems, designing solutions, making decisions or investigating activities. Projects provide workers with autonomy over a long period of time, and the results are actual products or presentations. A project always has a clear goal (Braguglia \& Jackson, 2012).

\subsection{Perspectives on Project-Based Teaching}

Project-based teaching has been defined in many different ways depending on the subject and level of study. Project-based teaching is often associated with career orientation and aims to apply knowledge to real life. People often integrate the fields of mathematics, physics, informatics, etc., when doing learning projects (Mills \& Treagust, 2003).

Project-based teaching motivates students to learn, collaborate, and apply their knowledge to learning tasks. By collecting information, using technology, using communication skills, teamwork, and solving complex problems, students develop their critical thinking, independent thinking and other qualities and capabilities for themselves (Bell, 2010). Project-based teaching is a teaching method that develops students comprehensively. This teaching method is designed around learning units to encourage students to participate in researching and creating products. Project-based teaching focuses on providing solutions to relatively large learning problems. Students debate, exchange ideas, communicate ideas, make predictions, define plans, collect and analyze data, come up with new questions, and perfect learning products (Blumenfeld et al., 1991).

Project-based teaching is a teaching method that applies theory to the practice of learning tasks. This teaching method facilitates individual and group learning. Students develop their own qualities and competencies as well as cooperative skills (DeFillippi, 2001). Project-based teaching is a method that helps students master theoretical knowledge and become proficient in practice. It is an effective teaching method in today's rapidly changing science and technology context. Project-based teaching is based on questions and complex learning tasks that allow students to mobilize their knowledge to design and organize solutions to assigned tasks. Students have the opportunity to work together to solve interdisciplinary problems (Panasan \& Nuangchalerm, 2010). Project-based teaching is one of the most effective methods for teaching science topics as well as interdisciplinary topics. Project- 
based teaching gives students the opportunity to come up with their own knowledge-building solutions. Projectbased teaching puts students in an environment where real-world, contextual problem solving is required. Projects create a bridge between the theory learned in class and practical experience. Project-based teaching requires active participation and effort from students over a long period of time. Projects can suit a wide variety of students in different learning situations. Project-based teaching stimulates students and develops their skills to carry out learning tasks in practice. Students apply knowledge and creativity to solving real-life problems (Holubova, 2008).

Project-based teaching is a modern teaching method that takes advantage of active teaching methods to connect theory with real world problems. The core idea of the project teaching method is the student's experience, i.e., the student's ability to absorb new knowledge and apply this knowledge in real contexts. The teacher acts as a coordinator, designing open questions for students. Specifically, teachers carefully evaluate the experienced activities when students participate in learning projects. Project-based teaching can take place either within or outside the classroom (Efstratia, 2014). Project-based teaching is a special and sustainable teaching method that is appropriate to the real-world context. Project-based teaching encourages students to collaborate on a specific learning project. This learning project is often organized into tasks that answer prompting questions. Students learn to work individually as well as collectively to solve a complex problem. Through deliberate learning, students use their own experiences to make decisions. Students must cooperate closely to complete the assigned project (Gary, 2020). Project-based teaching is a way of teaching that brings to life ideas relating to career-oriented education. Project-based teaching is mainly concerned with holistic personal development, as well as the ability to work as a team by stimulating and motivating students to participate in learning projects (Heitmann, 1996).

Project-based teaching is a constructivist, student-centered teaching method that integrates real situations and contexts into the learning environment. There are many different interpretations of project-based teaching. It is a teaching method in which students design and produce scientific products. Project-based teaching is often used in relatively complex projects. The method is geared toward learners' essential needs, helping to improve academic achievement and strengthen group activities. Planning is essential to a successful project implementation. Teamwork and planning increase the independence and responsibility of the individual students because they have to plan their activities and set the goals they will need to accomplish individually or in groups, while also having to account for other individuals and groups. In addition to the requirements of knowledge, technical skills, and social skills (such as communication and cooperation), students must self-assess and negotiate. These social skills are increasingly important in society (Habók \& Nagy, 2016).

Project-based teaching is a collaborative, progressive, active, student-centered teaching method. Project-based teaching promotes active activities by engaging students to solve real-world problems in a collective learning environment. The goal of project-based teaching is for students to experience real-world problems. Students design projects, solve problems, make decisions, investigate, and manufacture products, and have opportunities to work independently. Project-based teaching takes place over a long period of time (Chowdhury, 2015).

Project-based teaching allows students to learn through the implementation of ideas. Students engage in realworld activities that are similar to activities typically carried out by professionals. Project-based teaching is a form of teaching that activates student learning to help students develop deeper knowledge. In project-based teaching, students undertake the same activities as scientists, mathematicians, and others. In the project class, students have the opportunity to investigate through questionnaires, propose hypotheses and explanations, discuss and reflect on ideas, and test new ideas (Krajcik \& Blumenfeld, 2005).

Project-based teaching is a method of teaching through experience and group work. Students create a plan to tackle a difficult, real-world, interdisciplinary problem. Students are granted a high degree of responsibility to come up with a way to handle project tasks (Solomon, 2003).

Project-based teaching is a teaching method that stimulates and brings into full play the capacities and qualities of learners. Through project-based teaching, students are able to communicate, create, and develop their thinking. Students are involved in investigation, discovery, exploration and decision-making. Specifically, students have the opportunity to experience real life and the connection between practice and theory. Students are usually organized into groups to work together. The project-based teaching method is based on constructivist theory. Project-based teaching focuses on conversation, listening, questioning, debating, and sharing (Kaldi, Filippatou, \& Govaris, 2011).

Project-based teaching is not only student-centered, but also helps students transform their scientific, theoretical knowledge into practice in daily life. Project-based teaching helps students become active and positive. Students tend to be inspired and passionate about the subject they are studying (Zhang, Hansen, \& Andersen, 2016). Project-based teaching is a method of stimulating attention and improving students' learning outcomes. Through project-based teaching, students increase their love of discovery and exploration. This teaching method is built on an emphasis on the natural curiosity of learners, allowing students to interact, ask questions, connect, communicate, and respond. Students participating in project learning always try hard and put in great effort. When learning through this method, they become more excited about what they are learning, less likely to be absent from school, and more disciplined. Project-based teaching creates connections between fields and subjects. This helps students to remember what they have learned and to make connections with the real world (Sawyer, 2013).

Project-based teaching makes learning more effective. Learners investigate and interact with issues. The questions in the learning projects are rich, realistic and relevant to the topic under study. Project-based teaching is derived from constructivist teaching and exploratory perspectives. Both constructivism and the point of discovery rely on students' individual thoughts, abilities, and activities to provide solutions. In project-based teaching, students are at the center of teaching and learning. Students are always actively improving their learning abilities. Project-based teaching helps students to be active, positive, and deep-learning. This teaching method is particularly effective for technical subjects. Project-based teaching creates opportunities for students to develop their competencies, helps students to better understand traditional teaching methods, and applies theoretical knowledge to practice (Jalinus, Nabawi, \& Mardin, 2017).

Project-based teaching is a systematic and effective teaching method that engages learners in real-world tasks to create their own products (Ajbilou, 2010). 
Project-based teaching is a student-centered teaching method based on three main factors. The first is contextual learning, the second is case-based learning, the third is learners' active participation in learning by experiencing, interacting and sharing their own knowledge (Kokotsaki, Menzies, \& Wiggins, 2016).

Project-based teaching is a teaching method based on providing solutions, discovery, cooperation, teamwork, the ability to apply technology when solving tasks, and ultimately the ability to perfect the product and to know how to present their product to their classmates (Krajcik \& Blumenfeld, 2005).

From the above definitions, we can conclude that project-based teaching is a student-centered teaching method, in which students build knowledge through experiencing learning tasks in which they plan, investigate, survey, and produce real products. Students work in groups to perform a variety of learning tasks. Students develop their critical thinking and take responsibility for their own activities. Project-based teaching is a particularly effective teaching method for developing learners' qualities and competencies.

\subsection{Features of Project-Based Learning}

The first defining feature of project-based teaching is that it is student-centered. The teacher is not the main factor that determines the success of project-based teaching; the teacher is only an instructor, an assistant, and the one who selects suitable projects for students. The heart of project-based teaching is student activities. Students conduct research activities, make decisions, communicate and take responsibility for the tasks they perform.

The second defining feature is that the teaching takes place through student experience. In traditional teaching, students learn knowledge from lectures, by listening and writing. After completing a certain amount of course content, students are tested on their mastery of the lecture - their knowledge and understanding. In contrast, in project-based teaching a sequence of scenarios is generated. Students explore the project content that they must address. In real life, projects are often the integration of many complex stages and knowledge. There is no right or wrong answer, as in traditional test questions. Instead, students must come up with sensible solutions based on an application of the knowledge and skills deemed necessary to solve the problem. These solutions form the student experience. The ultimate goal of learning is not to find the best answer to a question, but to train students to learn through project implementation, i.e., working through the steps of thinking, researching the topic, and developing a plan. In this method, the more students experience, the easier the project will be completed.

The third defining feature is that the project-based teaching method focuses on the learning process, rather than the product. This teaching method emphasizes problem-solving strategies. This is especially important in today's world of ever-changing technology. Project-based teaching involves transferring information or, more accurately, students' ability to find and generate information. Through project-based teaching methods, students can develop their competencies and qualities.

The fourth characteristic is group or team teaching. Students learn how to discuss and exchange ideas and problem-solving strategies. Students are responsible for solving their own problems as well as making suggestions to achieve the most complete product.

The fifth characteristic is that the teaching method develops critical thinking. This is the ability to analyze, synthesize and evaluate information, as well as to apply knowledge and information processing skills in a practical context. Learners must develop the skill of timely and creative decision-making (Uziak, 2016).

\subsection{Project-Based Teaching Process}

We propose a project-based teaching process that includes the following steps:

\section{Step 1. Propose a learning project}

The learning project must not be too difficult for the students' knowledge level. It can be delivered through a number of textbook and workbook lessons. The choice of the learning project depends on the capacity of the learner as well as whether or not the content will be attractive to students. In addition, the choice of learning project depends on many other factors, such as length of study, facilities, money, as well as the amount of effort to be invested in a learning project.

\section{Step 2. Identify groups, knowledge, skills, attitudes, outlines, and project implementation plans}

The tasks of the learning project must be assigned to the appropriate group. Groups with many excellent learners will perform the most difficult learning tasks. A group with few good learners will do the job they can. Each group will be scheduled to perform the assigned work on time. In addition, there must be a detailed outline for the entire project as well as a detailed outline for each project implementation team. The teacher must be the one to elaborate on the lesson plan. The lesson plan acts as a script for the teaching process. The lesson plan must be specific, systematic and flexible in its implementation.

\section{Step 3. Implementation of the project}

Teachers must organize, urge, support, advise, and evaluate the positive and negative sides of each group performing the task. Teachers must be flexible in adjusting the project if needed. Is the actual implementation of the project any different from the way it was scripted? If there are differences, what changes need to be made to suit the actual situation? The teacher is responsible for regulating the implementation of the project. Meanwhile, the students study and perform tasks. Students can go to the Internet to research materials to complete the assigned task. Students must report their progress according to the tasks assigned by the teacher. In the process of performing the task, if there are any questions or difficulties, students must report back to the teacher. The communication between students and teachers is an ongoing process throughout the project.

\section{Step 4. Acceptance of results and product presentation}

After completing the product, students will report back to the teacher and the class. During this period, students can exchange opinions and discuss their difficulties and the positives and negatives of the products made by their group, as well as give comments and suggestions to other groups.

Step 5. Evaluate the project

Teachers and other groups in the class evaluate a group's overall performance. Has the group's attitude and effort been positive? Has the group improved from week to week or milestone to milestone? Teachers should go in depth and closely follow each group to have a way to evaluate their process accurately and fairly. Thus, evaluation 
in this case consists of an assessment according to the quality and capacity of the learners, not just a test as in traditional methods. The critical thinking of the group and that of each individual student should be carefully assessed. The ways in which project topics are deepened and developed, as well as students' creativity in the implementation of the project, are factors that need to be scored in the evaluation.

\subsection{Advantages and Disadvantages of Project-Based Teaching}

Table-1. Project-based learning.

\begin{tabular}{|c|c|}
\hline Advantages & Disadvantages \\
\hline $\begin{array}{l}\text { There is no limit to the knowledge and amount of } \\
\text { information in the project implementation process. } \\
\text { Teachers help and support students in the process of } \\
\text { developing and improving their knowledge through } \\
\text { learning projects. }\end{array}$ & $\begin{array}{l}\text { There is a lack of experts in the project-based teaching method } \\
\text { because the teacher's experience, knowledge, skills, and ability } \\
\text { play an extremely large role in project-based teaching. } \\
\text { Therefore, it is not easy to train teachers to implement this } \\
\text { method. }\end{array}$ \\
\hline $\begin{array}{l}\text { An effective method of evaluating the learning } \\
\text { process. The method helps develop students' ability } \\
\text { to evaluate and make decisions. Because it promotes } \\
\text { group activities, project-based teaching helps } \\
\text { develop students' social skills, emotional } \\
\text { intelligence, and communication skills. }\end{array}$ & $\begin{array}{l}\text { The money and effort required for implementing a project- } \\
\text { based teaching method are not inconsiderable. In order to } \\
\text { pursue projects that are feasible and applicable in practice, } \\
\text { teachers must have support from schools and social } \\
\text { organizations. Otherwise, finance is a factor that can } \\
\text { significantly restrict this teaching method. }\end{array}$ \\
\hline $\begin{array}{l}\text { Students show improved cognitive skills and } \\
\text { improved learning outcomes. Students show } \\
\text { reduced anxiety and active learning. }\end{array}$ & $\begin{array}{l}\text { The duration of project-based teaching is a challenge if the } \\
\text { project lasts many days or weeks. Whether students are } \\
\text { affected by the need to focus on projects is also a factor to } \\
\text { consider. The focus on the study project must not distract } \\
\text { from other subjects. Students must read and study a large } \\
\text { number of documents to complete the project. }\end{array}$ \\
\hline $\begin{array}{l}\text { Students learn through real-world projects that help } \\
\text { develop their ability to integrate their learning. }\end{array}$ & $\begin{array}{l}\text { The assessment of project-based teaching is not easy. The } \\
\text { evaluation of the process requires teachers to spend a lot of } \\
\text { effort to compare, weigh and measure workloads, attitudes, } \\
\text { levels of understanding, cognitive ability, positivity, and the } \\
\text { progress of each group and each student. If the teacher does } \\
\text { not pay close attention, the assessment will be ineffective. The } \\
\text { assessment of each group and individual is difficult because the } \\
\text { progress and capacity of each group and individual differ. }\end{array}$ \\
\hline
\end{tabular}

Note: Efstratia (2014).

\section{Results and Analysis}

\section{Step 1. Propose a learning project}

A fragrant room brings us a sense of relaxation and comfort and make it easier for us to fall asleep. Today, many people choose to use aromatic wax because of the many benefits that it brings to our living space. The scent in the room contributes to destroying insects that cause disease and protecting the family space. After a tiring day, when we go home, we can smell the pleasant scents emanating from the aromatic wax and will surely feel refreshed and comfortable, relieving the stresses of life (see Figure 1). Given all these benefits, should we have aromatic wax bars in our room? If we are afraid that the aromatherapy wax products that are available on the market contain chemicals that can be harmful to our health with long-term use, we can make aromatherapy wax from natural ingredients. They are easy to make, economical and do not affect our health. The production of aromatic wax is not too difficult for junior high school students and above. The products can be made by students themselves, helping them promote their creativity as well as stimulating their curiosity, research skills, the independent study of subjects and the application of their learned knowledge into practice. Therefore, we propose a learning project involving the production of aromatic wax. The target group is 6th grade students. The time set aside for this is 2 weeks at home and 45 minutes to report on their products in class. It is organized in the practice room of the school.

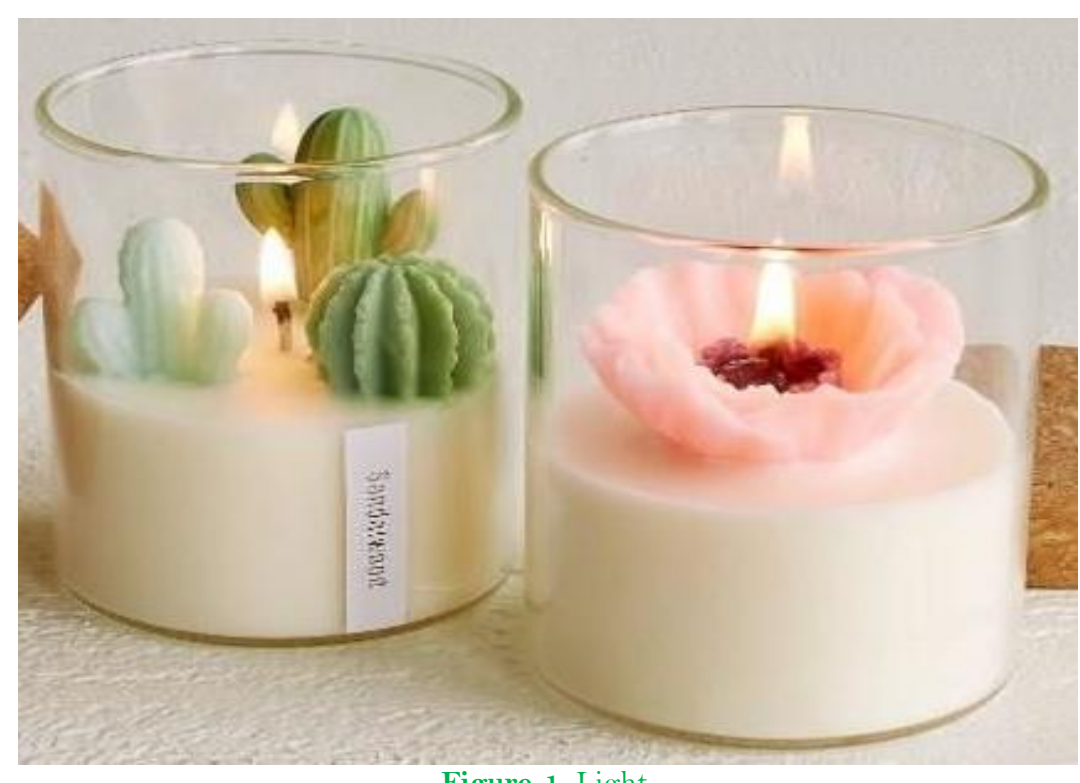

Source: Scented Candles (2020).

Figure-1. Light. 
Step 2. Identify groups, knowledge, skills, attitudes, outlines, and project implementation plans

First, we determine the basic knowledge required for the teaching topic of aromatic wax production. The project covers the following STEM knowledge (see Table 2):

Table-2. Factors

\begin{tabular}{l|l}
\hline Components of STEM & Application knowledge \\
\hline Science $(\mathrm{S})$ & $\begin{array}{l}\text { Apply knowledge of solidification, melting, and amorphous solids to explain the } \\
\text { process of creating aromatic wax. }\end{array}$ \\
\hline Technology $(\mathrm{T})$ & $\begin{array}{l}\text { State the use of tools for creating scented wax, including alcohol lamps, ceramic cups, } \\
\text { molds, etc. Describe the properties of the crayons. Use of alcohol lamps, porcelain } \\
\text { cups, stainless steel spoons to melt wax. Use of molds to shape the aromatic wax. }\end{array}$ \\
\hline Engineering $(\mathrm{E})$ & $\begin{array}{l}\text { Read the DIY aromatic wax guide. Make your own scented wax from available } \\
\text { ingredients according to the instruction manual. Map the process of making } \\
\text { aromatherapy waxes from crayons. }\end{array}$ \\
\hline Mathematics $(\mathrm{M})$ & Proportional relationship between melting temperature and mass of solids. \\
\hline
\end{tabular}

The knowledge of the manufacture of aromatherapy wax includes:

3.1. Melting and Freezing

The transition from a solid to a liquid is called melting. Temperature characteristics during the melting of solids include:

- Most substances melt at a specific temperature, which is called the melting point. The melting point of different substances is different.

- During the melting period, the temperature of the object does not change.

The transition from a liquid to a solid is called solidification. Temperature characteristics of the solidification process include:

- Most substances solidify at a specific temperature, which is called the freezing point. Substances that melt at a certain temperature, solidify at that temperature.

- During the freezing time, the temperature of the object does not change.

\section{Aromatic wax (candles)}

- Aromatic wax candles are utensils that provide light and heat in everyday life. In addition, candles are also used as a decorative item, creating a comfortable fragrance for the space in your room.

- The main ingredient when making scented wax is margarine.

- Margarine is hydrocarbon. It has an even number of carbon atoms (usually between $12 \mathrm{C}$ and $24 \mathrm{C}$ ) in solid form.

Margarine is an amorphous solid. It has no definite geometry, and its shape depends on the mold.

The melting of butter is the process of converting from solid butter to liquid butter. Butter is an amorphous solid, so it has no specified melting point (butter melts at between $32^{\circ} \mathrm{C}$ and $350^{\circ} \mathrm{C}$ ).

- The coagulation of margarine is the process of converting from a liquid to a solid. Butter does not have a specified freezing temperature and can decrease in volume when solidified.

The topic's objectives include the following elements. In terms of knowledge, students will be able to define the melting temperature, and show the dependence of the melting temperature and the volume of solids.

Students will be able to describe the characteristics of melting temperature and freezing point of crystalline solids and amorphous solids, as well as the applications related to melting and solidifying in life and engineering.

In terms of skills, students will learn to manipulate tools and chemicals, develop teamwork skills, analyze reallife phenomena in a scientific way, map out the aromatic wax production process, as well as self-cast aromatic wax. In terms of attitude, students will learn to comply with safety regulations in the process of aromatic wax production as well as increase their interest in learning and exploring science associated with real life, motivating students to develop and create new things.

\section{Step 3. Implementation of the project}

First, we prepare the tools and materials to produce aromatic wax. As shown in Table 3, these tools and materials include: crayons (Figure 2), essential oils (Figure 3), glass bottles (Figure 4), wick yarn (Figure 5), alcohol lamp (Figure 6), porcelain cups (Figure 7), asbestos mesh (Figure 8), tripod (Figure 9), stainless steel spoon (Figure 10), scissors (Figure 11). 


\begin{tabular}{|c|c|c|c|}
\hline Tools and materials & Illustrated images & Tools and materials & Illustrated images \\
\hline Crayons & 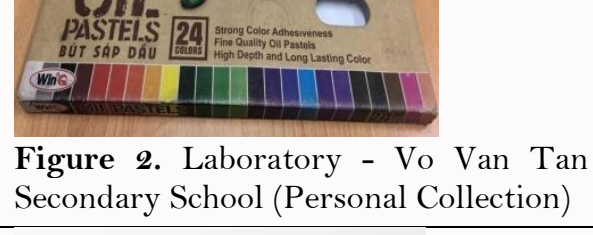 & Essential oils & $\begin{array}{l}\text { Figure 3. Laboratory - Vo } \\
\text { Van Tan Secondary School } \\
\text { (Personal Collection) }\end{array}$ \\
\hline Glass bottles & $\begin{array}{l}\text { Figure 4. Tool } \\
\text { Source: Glass Bottles (2020) }\end{array}$ & Wick yarn & 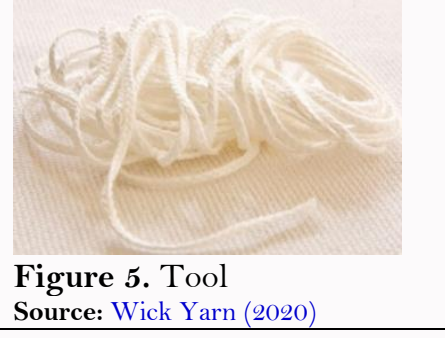 \\
\hline Alcohol lamp & $\begin{array}{l}\text { Figure 6. Tool } \\
\text { Source: Alcohol Lamp (2018) }\end{array}$ & Porcelain cups & $\begin{array}{l}\text { Figure 7. Tool } \\
\text { Source: Porcelain Cups (2015) }\end{array}$ \\
\hline Asbestos mesh & $\begin{array}{l}\text { Figure 8. Tool } \\
\text { Source: Asbestos Mesh (2020) } \\
\end{array}$ & Tripod & $\begin{array}{l}\text { Figure 9. Tool } \\
\text { Source: Tripod (2020) } \\
\end{array}$ \\
\hline Stainless steel spoon & $\begin{array}{l}\text { Figure 10. Tool } \\
\text { Source: Coffee Spoon (2020) }\end{array}$ & Scissors & $\begin{array}{l}\text { Figure 11. Tool } \\
\text { Source: Scissors (2020) }\end{array}$ \\
\hline
\end{tabular}

The project-based teaching activities are implemented through the teacher and student activities described in Table 4:

Table-4. Teaching in class

\begin{tabular}{|c|c|}
\hline Teacher Activities & Student Activities \\
\hline \multicolumn{2}{|l|}{ Activity 1: Propose and assign problems to students } \\
\hline $\begin{array}{l}\text { Problem: To have light during power outages or times } \\
\text { when there is no electricity, what should we do? } \\
\text { Introduction to candles (scented wax). } \\
\text { Divide into } 2 \text { groups (A, B) and assign the following } \\
\text { tasks: } \\
\text { - Ask groups to read the documentation. Learn the } \\
\text { process of making aromatic wax from crayons and } \\
\text { essential oils. } \\
\text { - Find out the use of aromatic wax for human life. } \\
\text { - Perform the tasks: } \\
\text { + Design the aromatic wax production process. } \\
\text { + Make aromatic wax. }\end{array}$ & The groups perform the tasks assigned by the teacher. \\
\hline \multicolumn{2}{|l|}{ Activity 2: Perform the tasks } \\
\hline $\begin{array}{l}\text { Step 1: The teacher organizes group activities for } \\
\text { students. The teacher gives study cards to students. } \\
\text { - Introduction of materials. } \\
\text { - Introducing the aromatic wax production process. } \\
\text { - Problems encountered in the implementation process. }\end{array}$ & $\begin{array}{l}\text { The groups send representatives to present the knowledge } \\
\text { they have learned. They design a diagram of the process of } \\
\text { making aromatherapy wax. Read the instruction manual, } \\
\text { complete study cards and prepare a report. } \\
\text { Some pictures of the presentations (Figure 12, Figure 13): }\end{array}$ \\
\hline
\end{tabular}




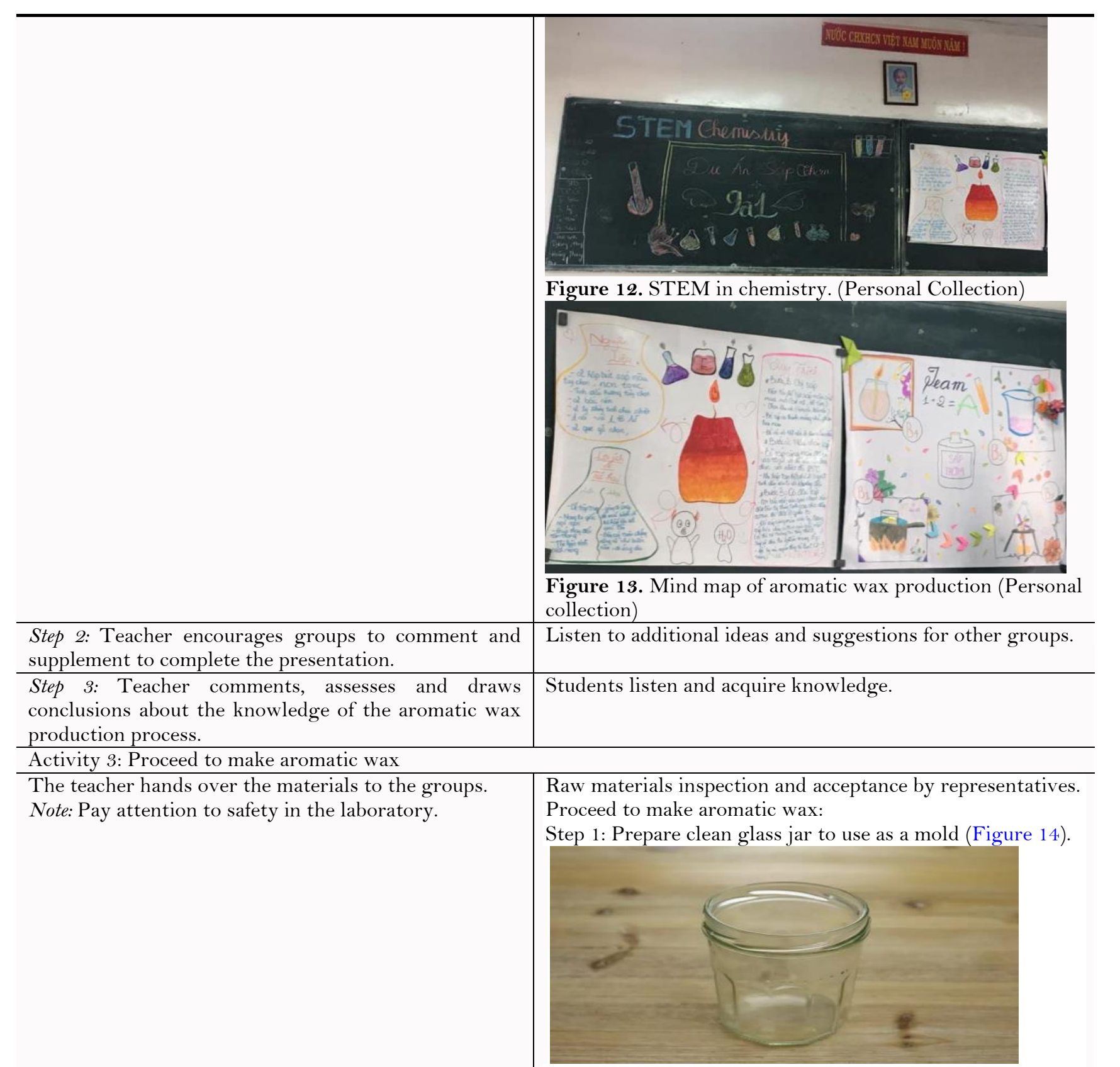

Figure 14. Prepare a clean glass jar

Source: Prepare a Clean Glass Jar (2018)

You can choose the mold according to your preferences to create a variety of patterns.

Step 2: Put margarine in a ceramic cup, melt margarine over an alcohol lamp.

- When melting butter over an alcohol lamp, be careful to avoid burns.

When the butter is completely melted, you will notice that the margarine mass has decreased. Next use a spoon to stir the mixture.

Step 3: Melt the crayon over an alcohol lamp flame.

- Choose your favorite crayon (Figure 15), smash it slightly to melt over an alcohol lamp flame more easily. Each crayon takes a different amount of time to melt, test it every 2-3 minutes to check how well it is melting. The amount of crayon we use is quite small, so it should only take 4 minutes to melt them all.

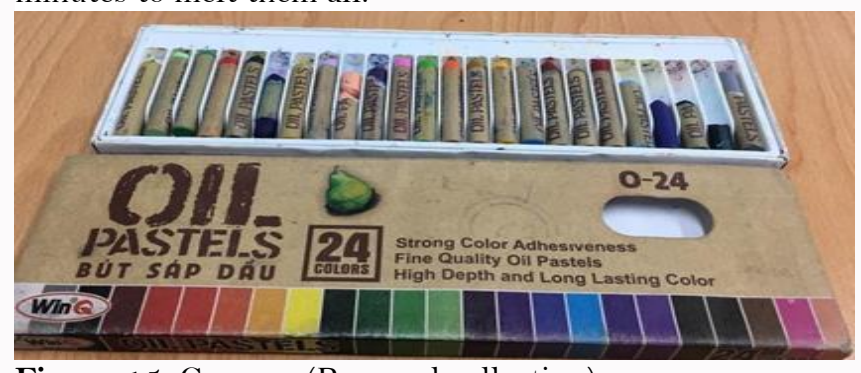

Figure 15. Crayons (Personal collection)

Step 4: Pour melted crayon into the glass jar to color the scented wax (Figure 16). 


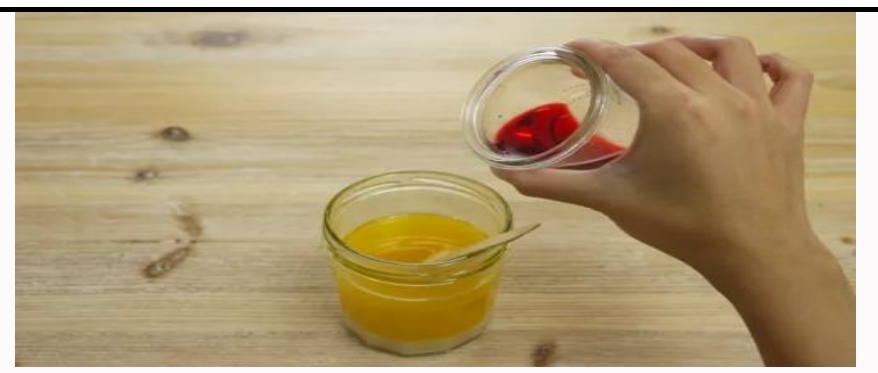

Figure 16. Pour crayon into the glass jar (Personal collection)

Step 5: Add essential oils (Figure 17) to add fragrance to the wax.

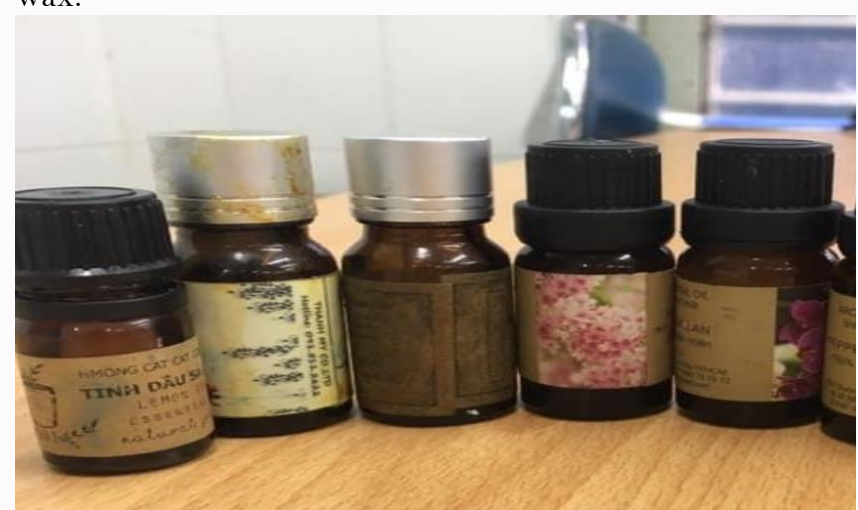

Figure 17. Laboratory - Vo Van Tan Secondary School (Personal collection)

Add half a tablespoon of your favorite essential oil to the jar. Then stir until the essential oil completely blends into the candle mixture in the bottle.

Step 6: Cut a piece of cotton about $40 \mathrm{~cm}$ long to create a wick.

You don't need a special fiber to create a wick, you can use anything made of $100 \%$ cotton. It is important to choose yarn that is made of $100 \%$ cotton, otherwise the candle will not burn properly (Figure 18).

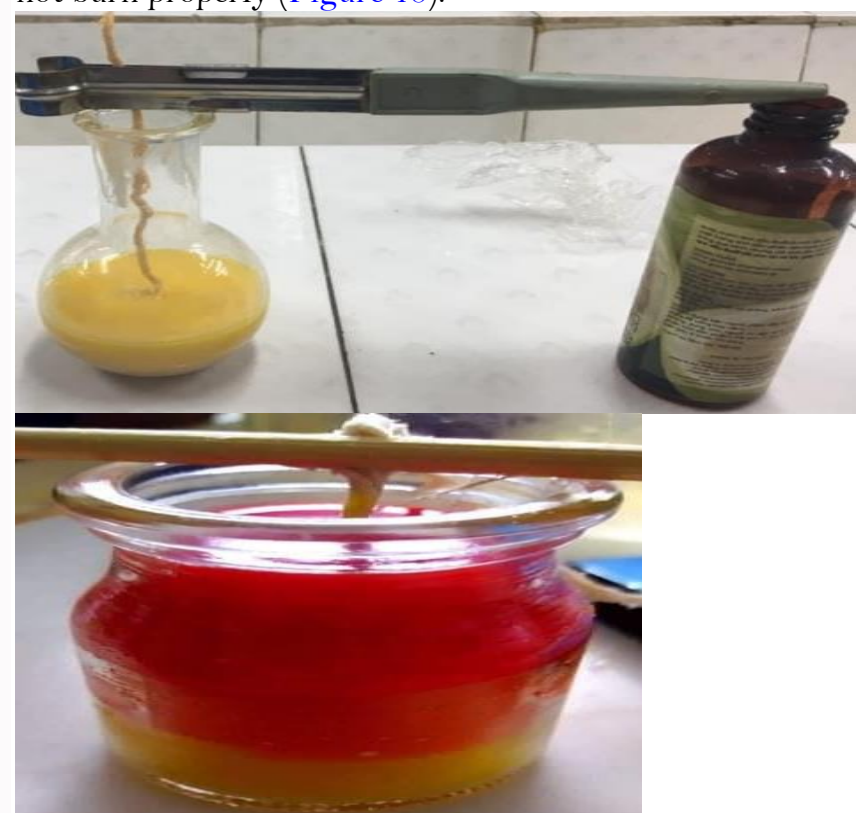

Figure 18. Laboratory - Vo Van Tan Secondary School (Personal collection)

Tie the other end of the wick to the middle of a wooden stick (you can use the same stick used to stir the mixture in the beginning) to keep the top of the wick straight while you wait for the mixture to set.

Step 7: Freeze for one hour.

Wait until the jar has cooled a little, then carefully place it in the refrigerator for about an hour.

Finished products (Figure 19): 


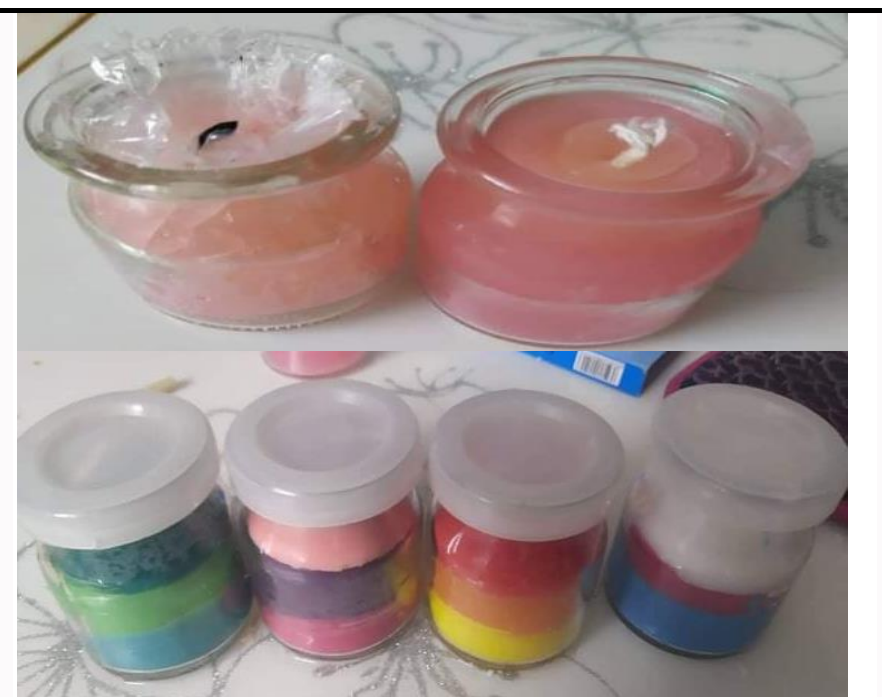

Figure 19. Laboratory - Vo Van Tan Secondary School (Personal collection)

Step 8: Light the candle and enjoy the results

Now it is time to enjoy this wonderful creation. Sit back and enjoy this sweet and pleasant fragrance. The candle jars are easy to light and are extremely helpful in relaxing your tired muscles (Figure 20, Figure 21, Figure 22, Figure 23, Figure 24, Figure 25, Figure 26, Figure 27).

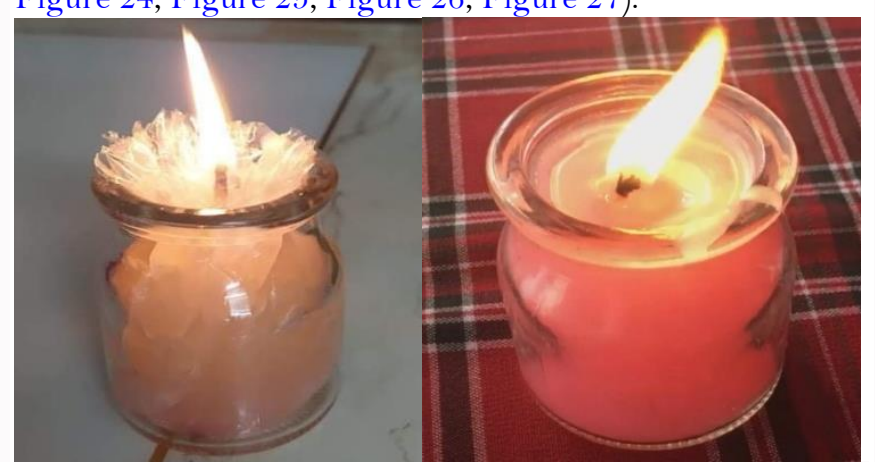

Figure 20. Laboratory - Vo Van Tan Secondary School (Personal collection)

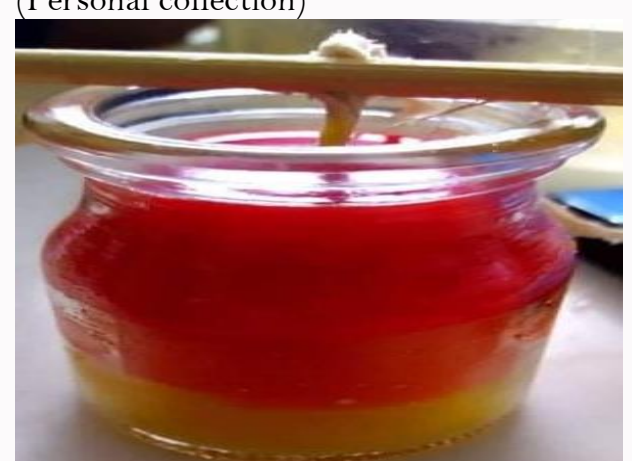

Figure 21. Fixing the wick - Group A students (Personal Collection)

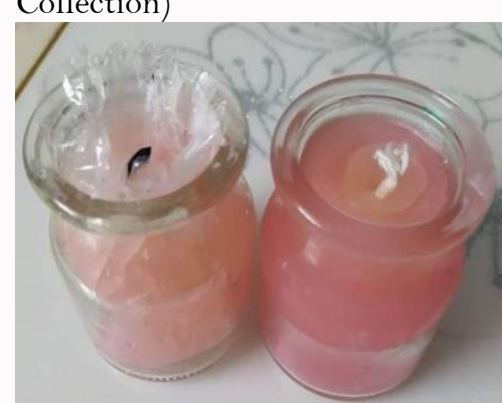

Figure 22. Finished products - Group A (Personal Collection)

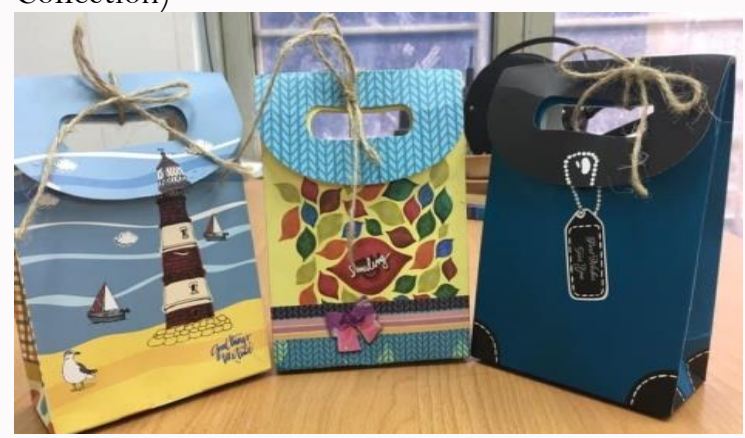

Figure 23. Finished products as gifts (Personal Collection) 


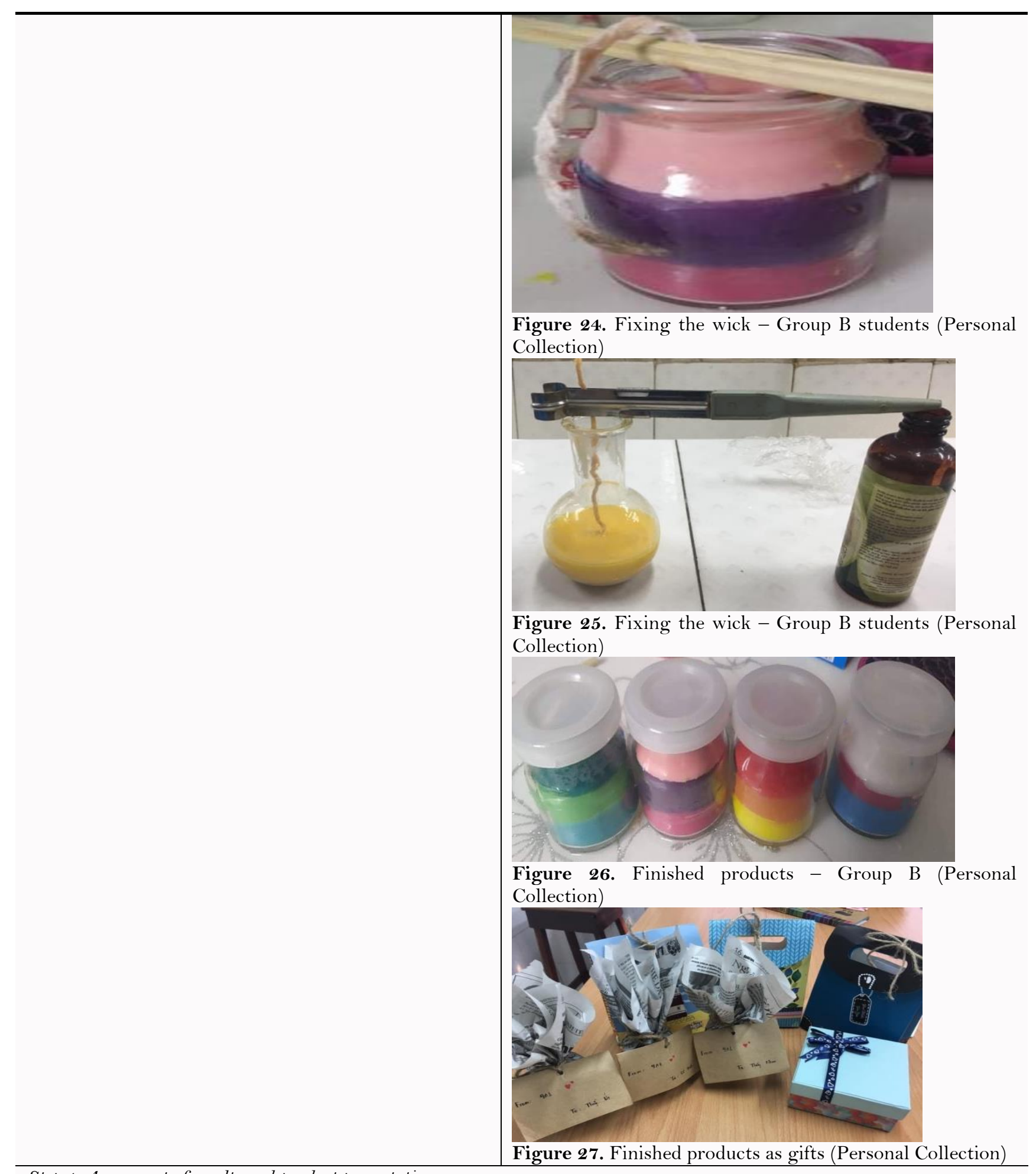

Step 4. Assessment of results and product presentation

The teacher asks groups to report on their assessment of the results.

- Ask groups to send representatives to report on their Group representatives report (Figure 28, Figure 29):

products.

- Teachers organize for students to discuss and make suggestions on each group's products.

- The teacher comments on each group's work progress and results.

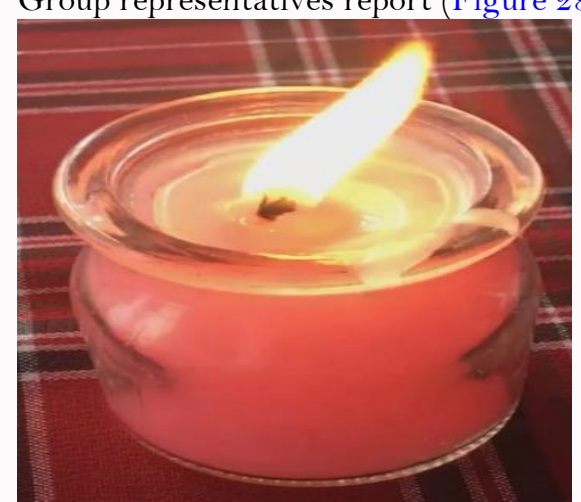

Figure 28. Group A (Personal Collection)

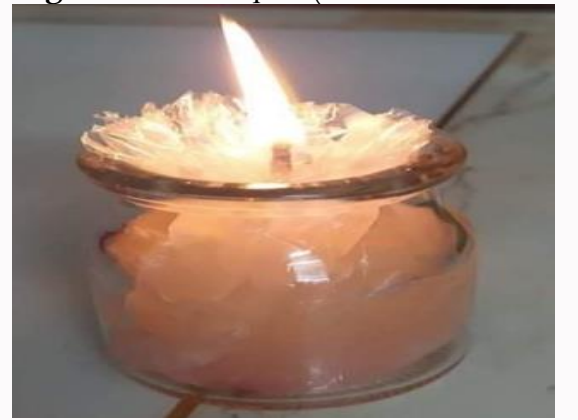

Figure 29. Group B (Personal Collection) 
Step 5. Evaluate the project

To evaluate the project, students should complete a learning product assessment form (see Table 5).

Table-5. STEM form

\section{Study Card on the Stem Topic: Producing Aromatic Wax}

Full name: ...........................

Class: ....................................

Group: ................................

1. Ingredients for aromatic wax

- What kind of a solid is margarine? What are the melting and freezing point characteristics of margarine?

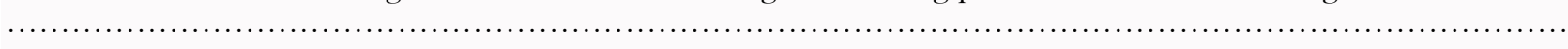

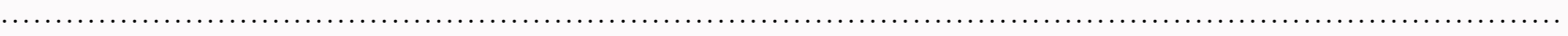

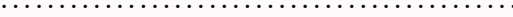

2. The process of making aromatic wax

- Map out the process of making aromatic wax from margarine and crayons.

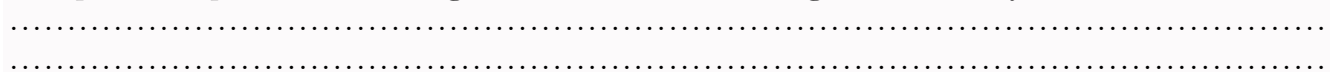

- In the process of making scented wax, at what stage does the melting take place? At what stage does the freezing take place?

\section{Perform:}

- Teachers should design their own product self-evaluation sheets, teacher-commented evaluation sheets, and questionnaires about students' interests after completing the topic. This is a very meaningful and necessary activity at the end of the STEM project.

- The product scores for each group are calculated as the average of the points evaluated by the group of students and teachers.

Teachers supply the evaluation criteria (Table 6, Table 7):

\begin{tabular}{|c|c|c|c|}
\hline \multirow[t]{2}{*}{ Evaluation criteria } & \multicolumn{3}{|l|}{ Level } \\
\hline & Level 1 (1 point) & Level 2 ( 2 points) & Level 3 (3 points) \\
\hline Product & Product needs work. & $\begin{array}{l}\text { Finished product but } \\
\text { limited aesthetics. }\end{array}$ & $\begin{array}{l}\text { Finished product with high } \\
\text { aesthetic value. }\end{array}$ \\
\hline Product presentation & $\begin{array}{l}\text { The presentation is long, } \\
\text { rambling and confusing for } \\
\text { the audience. }\end{array}$ & $\begin{array}{l}\text { The presentation is short, } \\
\text { logical, full of content. }\end{array}$ & $\begin{array}{l}\text { The presentation is short, } \\
\text { logical, full of content. It } \\
\text { includes information on how to } \\
\text { make aromatic wax from other } \\
\text { materials. }\end{array}$ \\
\hline
\end{tabular}

\begin{tabular}{|c|c|c|c|}
\hline \multirow[t]{2}{*}{ Evaluation criteria } & \multicolumn{3}{|l|}{ Levels } \\
\hline & Level 1 (1 point) & Level 2 (2 points) & Level 3 (3 points) \\
\hline Participation in group activities & $\begin{array}{l}\text { They do not actively } \\
\text { participate in group } \\
\text { activities and often } \\
\text { work separately. }\end{array}$ & $\begin{array}{l}\text { They join in some } \\
\text { group activities. }\end{array}$ & $\begin{array}{l}\text { They have self- } \\
\text { discipline and actively } \\
\text { participate in all group } \\
\text { activities. }\end{array}$ \\
\hline Group discussion & $\begin{array}{l}\text { They do not pay } \\
\text { attention to the group's } \\
\text { tasks, so the ideas they } \\
\text { contribute are not } \\
\text { related to the } \\
\text { discussion. }\end{array}$ & $\begin{array}{l}\text { They have listened but } \\
\text { have not given any } \\
\text { personal opinion. }\end{array}$ & $\begin{array}{l}\text { They listen attentively } \\
\text { and supply the group } \\
\text { with many good ideas. }\end{array}$ \\
\hline Reports on group tasks & $\begin{array}{l}\text { No reports on the } \\
\text { results of the group's } \\
\text { tasks. }\end{array}$ & $\begin{array}{l}\text { The report has been } \\
\text { completed but is not } \\
\text { logical, there are many } \\
\text { shortcomings that } \\
\text { need to be added. }\end{array}$ & $\begin{array}{l}\text { The report is completed } \\
\text { logically and } \\
\text { completely. }\end{array}$ \\
\hline
\end{tabular}

Teachers give each student a concrete evaluation as follows (Table 8).

\section{Conclusion}

Project-based teaching is a student-centered teaching method. It is based on constructivist theory and aims to create excitement and stimulate students' exploration and discovery. Students experience real situations. Projectbased teaching methods are based on individual activities and group activities. Students display a positive attitude, not afraid of difficulties and not struggling to complete learning tasks. They are capable of creating products and are facilitated by the school and parents to complete the project. This method helps students develop their communication skills and cooperation skills and particularly helps to shape learners' qualities and competencies. Students foster and improve their critical thinking. Students also practice reporting and presenting their results to groups of classmates. Through teaching on the topic of aromatic wax, we have found that students are excited to participate in the learning and production process. Aromatic wax products bring us a sense of relaxation and 
comfort and help us to fall asleep more easily. Their scent contributes to destroying insects that cause disease and protects the family space.

Table-8. Personal self-assessment

\begin{tabular}{|c|c|c|c|}
\hline \multirow[t]{2}{*}{ Evaluation criteria } & \multicolumn{3}{|l|}{ Levels } \\
\hline & Level 1 (1 point) & Level 2 (2 points) & Level 3 (3 points) \\
\hline Enthusiastic participation in work & $\begin{array}{l}\text { They participate in the } \\
\text { work but } \\
\text { enthusiastically. }\end{array}$ & $\begin{array}{l}\text { They participate in the } \\
\text { work. }\end{array}$ & $\begin{array}{l}\text { They participate in the } \\
\text { work actively } \\
\text { enthusiastically. }\end{array}$ \\
\hline Offering new opinions and ideas & $\begin{array}{l}\text { The do not listen and do } \\
\text { not offer new opinions } \\
\text { and ideas. The opinions } \\
\text { and ideas they offer are } \\
\text { not related to the } \\
\text { discussion. }\end{array}$ & $\begin{array}{l}\text { They listen, but give old } \\
\text { opinions and ideas related } \\
\text { to the discussion. }\end{array}$ & $\begin{array}{l}\text { They listen attentively and } \\
\text { offer new opinions and } \\
\text { ideas. }\end{array}$ \\
\hline $\begin{array}{lrr}\text { Creating a friendly } & \text { collaborative } \\
\text { environment } & & \end{array}$ & $\begin{array}{l}\text { They do not create a } \\
\text { friendly, collaborative } \\
\text { environment. }\end{array}$ & $\begin{array}{l}\text { They collaborate with } \\
\text { other students but not in } \\
\text { a friendly way. }\end{array}$ & $\begin{array}{l}\text { They create a friendly, } \\
\text { collaborative environment. }\end{array}$ \\
\hline Organizing and guiding the group & $\begin{array}{l}\text { They do not organize or } \\
\text { guide the group. }\end{array}$ & $\begin{array}{l}\text { They organize the group } \\
\text { but do not guide it. }\end{array}$ & $\begin{array}{l}\text { They organize and guide } \\
\text { the group enthusiastically. }\end{array}$ \\
\hline Completing the task efficiently & $\begin{array}{l}\text { They do not complete the } \\
\text { task efficiently. }\end{array}$ & $\begin{array}{l}\text { They complete the task } \\
\text { but need guidance. }\end{array}$ & $\begin{array}{l}\text { They complete the task } \\
\text { efficiently. }\end{array}$ \\
\hline
\end{tabular}

\section{References}

Ajbilou, R. (2010). Project-based learning. Retrieved from: https://www.academia.edu/4606361/Project Based Learning.

Alcohol Lamp. (2018). Retrieved from: https://sudospaces.com/vietchem-com-vn/2018/07/den-con-thuy-tinh-soda-lime-mediumduran.jpg.

Asbestos Mesh. (2020). Retrieved from: https://cf.shopee.vn/file/74d993e94fobe64c0ae64be745f66fc9.

Bell, S. (2010). Project-based learning for the 21 st Century: Skills for the future. The Clearing House: A Journal of Educational Strategies, Issues and Ideas, 83(2), 39-43. Available at: https://doi.org/10.1080/00098650903505415.

Blumenfeld, P. C., Soloway, E., Marx, R. W., Krajcik, J. S., Guzdial, M., \& Palincsar, A. (1991). Motivating project-based learning: Sustaining the doing, supporting the learning. Educational Psychologist, 26(3-4), 369-398. Available at: https://doi.org/10.1080/00461520.1991.9653139.

Braguglia, K. H., \& Jackson, K. A. (2012). Teaching research methodology using a project-based three course sequence critical reflections on practice. American Journal of Business Education (AJBE), 5(3), 347-352. Available at: https://doi.org/10.19030/ajbe.v5i3.7007.

Chowdhury, R. K. (2015). Learning and teaching style assessment for improving project-based learning of engineering students: A case of United Arab Emirates University. Australasian Journal of Engineering Education, 20(1), 81-94. Available at: https://doi.org/10.7158/D13-014.2015.20.1.

Coffee Spoon. (2020). Retrieved from: https://chefstore.vn/pd/tlthia-inox-cao-cap-dai-1 12-mm-thia-ca-phe-bo-4-chiec.

DeFillippi, R. J. (2001). Introduction: Project-based learning, reflective practices and learning outcomes. Management Learning, 32(1), 5-10.

Efstratia, D. (2014). Experiential education through project based learning. Procedia - Social and Behavioral Sciences, 152, 1256-1260. Available at: https://doi.org/10.1016/j.sbspro.2014.09.362.

Gary, K. (2020). Project-based learning. Compuitng Education, 48(9), 98-100.

Glass Bottles. (2020). Retrieved from: https://salt.tikicdn.com/ts/tmp/a2/e9/55/ae2975f702e43668cc08835d7b3a8ea8.png.

Habók, A., \& Nagy, J. (2016). In-service teachers' perceptions of project-based learning. SpringerPlus, 5(1), 1-14. Available at: https://doi.org/10.1186/s40064-016-1725-4.

Heitmann, G. (1996). Project-oriented study and project-organized curricula: A brief review of intentions and solutions. European Journal of Engineering Education, 21(2), 121-131. Available at: https://doi.org/10.1080/03043799608923395.

Holubova, R. (2008). Effective teaching methods - Project-based learning in physics. US-China Education Review, 5(12), 27-36. Available at: https://files.eric.ed.gov/fulltext/ED504949.pdf.

Jalinus, N., Nabawi, R. A., \& Mardin, A. (2017). The seven steps of project based learning model to enhance productive competences of vocational students. Advances in Social Science, Education and Humanities Research 102, 251-256.

Kaldi, S., Filippatou, D., \& Govaris, C. (2011). Project-based learning in primary schools: Effects on pupils' learning and attitudes. Education, 39(1), 35-47. Available at: https://doi.org/10.1080/03004270903179538.

Kokotsaki, D., Menzies, V., \& Wiggins, A. (2016). Project-based learning: A review of the literature. Improving Schools, 19(3), 267-277. Available at: https://doi.org/10.1177/1365480216659733.

Krajcik, J. S., \& Blumenfeld, P. C. (2005). Project-based learning. The cambridge handbook of the learning sciences (pp. 317-333). England: Cambridge University Press.

Mills, J. E., \& Treagust, D. F. (2003). Engineering education-Is problem-based or project-based learning the answer. Australasian Journal of Engineering Education, 3(2), 2-16.

Nguyen, M. D. (2020). Using the project-based learning to combine the experience activities in teaching the integrated topic "Chemical fertilizer-the friend of farmers. Vietnam Journal of Education, 473, 28-35.

Panasan, M., \& Nuangchalerm, P. (2010). Learning outcomes of project-based and inquiry-based learning activities. Journal of Social Sciences, $6(2), 252-255$.

Pham, H. B. (2013). Aplying the project-based learning in Chemistry part The Chemistry of non-metal of upper secondary school. The Doctoral Dissertation, Hanoi National University of Education.

Porcelain Cups. (2015). Retrieved from: https://vattubk.com/wp-content/uploads/2015/07/bat-su-nung-150ml.jpg.

Prepare a Clean Glass Jar. (2018). Retrieved from: https://dothobattrang.vn/wp-content/uploads/2018/04/chuan-bi-lo-sach.png.

Sawyer, G. L. (2013). The effects of traditional teaching methods, project-based learning, and a blended teaching style on elementary students. The Degree of Doctor of Education in Leadership and Professional Practice, Trevecca Nazarene University.

Scented Candles. (2020). Retrieved from: https://s.meta.com.vn/img/thumb.ashx/Data/image/2020/03/18/cach-lam-nen-thom-14.jpg.

Scissors. (2020). Retrieved from: https://www.anlocviet.vn/upload/product/keof1001500x500-6086.jpg.

Solomon, G. (2003). Project-based learning: A primer. Technology and Learning-Dayton-, 23(6), 20-20.

Tripod. (2020). Retrieved from: http://hmhintraco.com/files/sanpham/649/1/jpg/kieng-ba-chan.jpg.

Uziak, J. (2016). A project-based learning approach in an engineering curriculum. Global Journal of Engineering Education, $18(2), 119-123$.

Wick Yarn. (2020). Retrieved from: https://hangphatcandle.com/wp-content/uploads/2020/02/Cach-lam-tim-bac-nen-2.jpg.

Zhang, Z., Hansen, C. T., \& Andersen, M. A. E. (2016). Teaching power electronics with a design-oriented, project-based learning method at the technical University of Denmark. IEEE Transactions on Education, 59(1), 32-38. Available at: https://doi.org/10.1109/TE.2015.2426674. 